\title{
Caution issued against use of morcellators
}

$\mathrm{H}$ ealth Canada has followed the US government's lead and issued an advisory on the potential danger of morcellators, tools used primarily in gynecological laparoscopic surgery. However, there is disagreement in Canada over whether an advisory is necessary.

Morcellators are used in laparoscopic surgery to grind up the uterine tissue or fibroids so they can be removed through tiny $1.5 \mathrm{~cm}$ incisions. However, according to the US Food and Drug Administration (FDA), in as many as 1 in 350 cases the tool accidentally chops up undetected cancer, which can cause it to spread.

The FDA has issued a long-awaited safety communication on the devices, saying they should not be used on perior postmenopausal women, or on any woman suspected of having cancer. According to the Nov. 24 announcement, a "black-box" warning must now appear on all morcellators sold in the US. This follows a preliminary notice in April and a two-day public hearing over the summer.

Health Canada's new advisory to hospitals, released Dec. 10, mirrors the FDA's recommendations.

Until recently, patients undergoing laparoscopic hysterectomy or fibroid removal were typically told that the risk of inadvertently spreading cancer during such procedures was about 1 in 10 000. Then in October 2013, a Boston physician, Amy Reed, underwent the procedure and as a result, her undetected leiomyosarcoma spread within her abdomen. Since then, she and her husband, cardiothoracic surgeon Hooman Noorchashm, have been campaigning to have morcellation stopped.

Some physicians feel that the warnings are overkill. "The morcellator is a basic tool for minimally invasive gynecological surgery," says Togas Tulandi, director, Division of Minimally Invasive Gynecology at the McGill University Health Centre in Montréal. He has been without a morcellator since August 2014, when Johnson \& Johnson, the largest manufacturer of the devices, voluntarily recalled its products. "I just wrote a letter to the university saying we should have it." He believes that

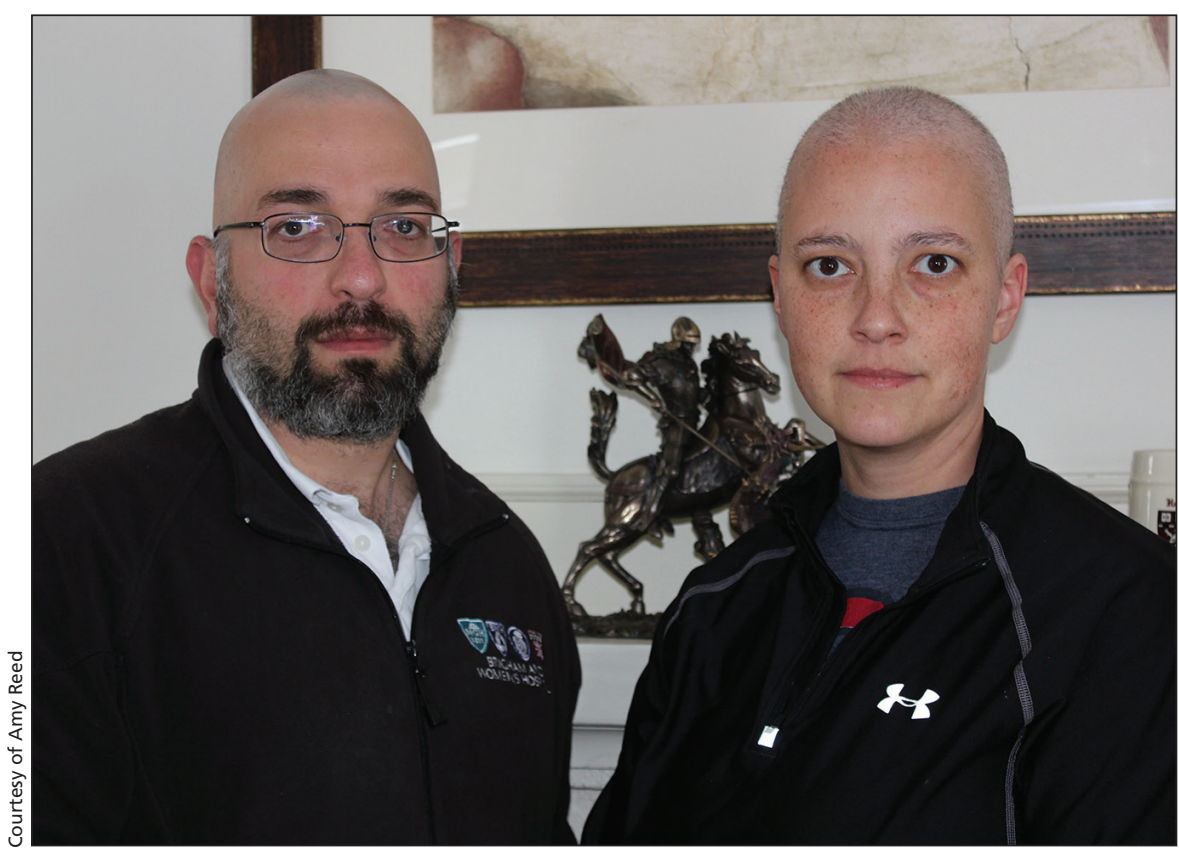

Boston physician Amy Reed underwent morcellation a year ago, and her undetected cancer subsequently spread. Since then she and her husband (left) have campaigned to halt the use of morcellators.

patients want the benefits of smaller incisions and that the university needs to train its students accordingly. While he agrees ... that postmenopausal women should not undergo morcellation, he says what's best for younger women is less clear.

Not everyone agrees with Tulandi. Dr. Sony Singh, director of Minimally Invasive Gynecology at the Ottawa Hospital, says that, even before this year's publicity, he was worried about inadvertent tissue spread and so almost never uses a power morcellator. Singh and his colleagues did go over their records, however, and found that in the past seven years, the Ottawa Region had 60 diagnoses of leiomyosarcoma, none of which were power morcellated.

$\mathrm{He}$ argues that doctors should always try to remove tissue intact, through the vagina or through a minilaparotomy. If that's not possible, he says, the tissue should be placed in a containment bag and cut into smaller pieces with a scalpel. "There are colleagues who feel we are being overly cautious," he admits.

Although leiomyosarcoma is an uncommon cancer, the prognosis is terrible and when morcellated, it's even worse, says Al Covens, head of gyneco- logic oncology at Odette Cancer Centre, Sunnybrook Hospital, Toronto. He thinks we have to develop better ways to diagnose these cancers preoperatively.

"Most women who have open surgery get through it just fine," says Jason Dodge, a gynecological oncologist at Toronto's Princess Margaret Hospital. And getting rid of morcellators will not end minimally invasive surgery, he says, pointing out that he does laparoscopic surgery on cancer patients all the time, without morcellators.

Dodge believes doctors need to develop standardized ways of discussing complex risks like these with patients, and he has noticed that the morcellation issue has triggered more of that. "If that's the upshot, then that's a great thing," he says. "But I'm not sure this is a Health Canada or an FDA issue, with all due respect." - Alison Motluk, Toronto, Ont.

CMAJ 2015. DOI:10.1503/cmaj.109-4962

\section{More News online}

To read more $C M A J$ news articles, visit cmaj.ca/site/home/news.xhtml 